\title{
Anti-Met Monoclonal Antibody Mixture Sym015
}

National Cancer Institute

\section{Source}

National Cancer Institute. Anti-Met Monoclonal Antibody Mixture Sym015. NCI

Thesaurus. Code C127906.

A mixture of two humanized immunog lobulin G1 (IgG1) monoclonal antibodies, Hu9006 and Hu9338, which recognize non-overlapping epitopes in the extracellular domain of the human hepatocyte growth factor receptor (MET; HGFR; c-Met), with potential antineoplastic activity. Upon administration, anti-MET monoclonal antibody mixture Sym015 targets and binds to the extracellular domain of MET, thereby preventing the binding of its lig and, hepatocyte growth factor (HGF). This may prevent activation of the receptor and MET-mediated signal transduction pathways. This inhibits MET -dependent tumor cell proliferation. MET, a receptor tyrosine kinase, is overexpressed on the cell surfaces of various solid tumor cell types; it plays a key role in cancer cell growth, survival, angiogenesis, invasion, and metastasis. 